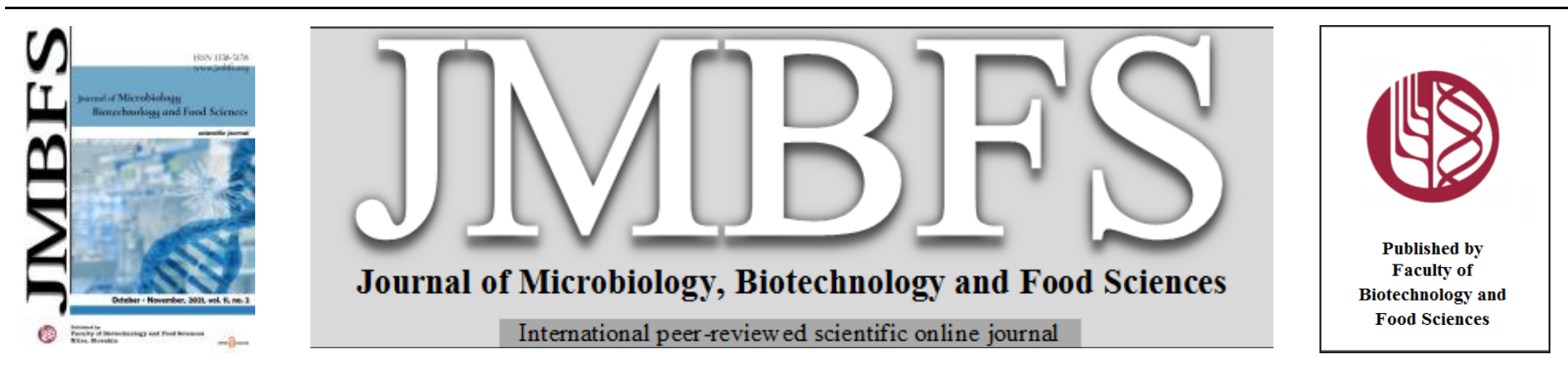

\title{
SCREENING AND ISOLATION OF THERMOPHILIC FUNGI OBTAINED FROM THREE SELECTED COMPOST WASTES SITES
}

\author{
Omodele Ibraheem ${ }^{*}$, Oluwafijimi Adetuyi ${ }^{1}$, Kalejaiye Sheriff ${ }^{1}$, Victoria John ${ }^{1}$, Wuraola Fayela ${ }^{1}$, John M. Ajayi $^{2}$ \\ Address(es): \\ ${ }^{1}$ Plants for Biotechnological Resources Research Group, Department of Biochemistry, Federal University Oye-Ekiti, PMB 373, Oye-Ekiti, Ekiti State, Nigeria. \\ ${ }^{2}$ Bioinformatics and Molecular Biology Unit, Department of Biochemistry, Federal University of Technology, Akure, Ondo State, Nigeria.
}

*Corresponding author: deleibraheem2007@yahoo.com

https://doi.org/10.15414/jmbfs.3537

\section{ARTICLE INFO}

Received 8. 4. 2020

Revised 18. 4. 2021

Accepted 23. 4. 2021

Published 1. 10. 2021

Regular article

OPEN $\partial_{\text {ACCESS }}$

\begin{abstract}
Thermostable enzymes have found applications in the improvement of products quality in various industries. Despite the discovery of several microorganisms as potential source of thermostable enzymes, more biodiversity explorations are currently been carried out for high activity enzymes producing isolates. The discovery of new isolates having these characters will allow to efficiently carry out reactions in various industrial processes that involve extreme conditions. This study was aimed to screen and isolate thermophilic fungi from three selected compost wastes sites (Palm oil mill, Wood chip piles and Abattoir dump), and identify potential producers of lipases, cellulases and proteases respectively. The thermophilic fungi were obtained from an equal depth of one meter in all the three collection sites with a temperature range of 40 to $45^{\circ} \mathrm{C}$ and later cultured at $70^{\circ} \mathrm{C}$. Further experimental screening analysis showed the presences of lipase, cellulase and protease producing fungi present in samples collected from palm oil mill, wood chips pills and abattoir dump site respectively. The isolated fungi were used for enzyme production in submerged fermentation for 10 days at $50^{\circ} \mathrm{C}$. Culture filtrate obtained from the medium of production were used for the assessment of enzymatic activity. The highest lipase, cellu lase and protease activities were obtained from isolates $3 \mathrm{~A}(56.56 \mathrm{U} / \mathrm{mL}), 3 \mathrm{~A}(38.35 \mathrm{U} / \mathrm{mL})$ and $2 \mathrm{~B}(3.0 \mathrm{U} / \mathrm{mL})$ respectively. These isolates with high enzymes activities were identified microscopically as Rhizopus sp., Aspergillus flavus and Neurospora sp. accordingly. We believed that these strains could be further exploited for numerous industrial applications that require thermophilic enzymes.
\end{abstract}

Keywords: Rhizopus sp., Aspergillus flavus, Neurospora sp., Thermophiles, Thermostable enzymes

\section{INTRODUCTION}

Dynamic application of enzymes in industrial processes has consequentially led to search for thermophilic fungi as they serve as a potential source of thermophilic enzymes such as lipolytic, proteolytic, cellulolytic, lignolytic and amylolytic enzymes which are used in the industries. Applications of these enzymes have found their ways in numerous industries such as; detergent, chemical, oil, food, brewing, pharmaceutical, leather, paper, dye and textile industries (Gomes and Steiner, 2004; Chrisnasari et al., 2018; Gulmus and Gormez, 2020). Enzymes produced by these thermophiles are thermostable, extreme $\mathrm{pH}$ tolerant and also possess high activity at other extreme environmental or industrial conditions (Ahirwar et al., 2017; Gulmus and Gormez, 2020).

Thermophiles are ubiquitously present in the environment, a number of them are found in industrial effluent, aquatic sediments, sludge, wood chip piles, composts site and other accrued organic matter that provides favorable conditions (warm, humid, and aerobic) for their growth (Lee et al., 2014; Ahirwar et al., 2017). Most enzymes obtained from thermophilic fungi often exhibit higher temperatures tolerance than those produced and extracted from mesophilic fungi. Some of these thermostable enzymes are stable between 50 to $80^{\circ} \mathrm{C}$ (Lee $\boldsymbol{e t}$ al. 2014), any temperature below $20^{\circ} \mathrm{C}$ has inhibited the activity and growth of true thermophilic fungi (Maheshwari et al., 2000; Ahirwar et al., 2017). Severa thermophilic fungi have also been isolated from environments associated with harsh conditions like high water pressure, absence of oxygen, high salinity and aridity (Lee $\boldsymbol{e t}$ al., 2014). Research has shown that many thermophilic organisms were mostly isolated from composts: prevalence of these microbes in compost sites is owing to their extreme temperatures, aerobic and humidity conditions present in the compost. In addition, compost also serve as a source of nutrients for the development of microorganism (Lee et al., 2014).

During metabolic activities of fungi found on composts, various organic materials are broken down to smaller organic molecules. The overall process of metabolism is made possible through the thermophilic fungi ability to secrete numerous enzymes capable of degrading composts (Raut et al., 2008). The thermophilic enzymes evaluated in this study are proteases, cellulases and lipases. These are largely required in the food industry to reduce time, energy and cost of operation (Raveendran et al., 2018). Proteases are known to catalyze peptide bonds in proteins through hydrolysis and thus they are used in brewing, meat tenderization and for milk coagulation (Patel et al., 2013). Proteases have also been used in improving food digestion, flavour and nutritional value as well as aiding emulsification and coagulation processes (Aruna et al., 2014) Cellulases act on cellulose and hydrolyze $\beta-1,4$ linkages found in carbohydrates to release glucose subunits. Classes of cellulases include endo- $(1,4)-\beta-\mathrm{d}$ glucanase (EC 3.2.1.4), exo-(1,4)- $\beta$-d-glucanase (EC 3.2.1.91) and $\beta$ glucosidases (EC 3.3.1.21) (Schülein, 1988). Fungi cellulases are used to increase yield, performance, clarification and improve stabilization in juices production processes (Dervilly et al., 2002). In addition, they are also utilized in the extraction of important phytochemicals such as phenolic and flavonoids from flowers, seeds and fruits (Kabir et al., 2015), while lipases hydrolyze long-chain of triglycerides. These enzymes are used in improving cheese texture, the flavour development in butter, the aroma in beverages alongside increasing the shelf life of baked products (Aravindan et al., 2007). Based on the commercial benefits of these enzymes, there is need to search for thermophiles that can produce thermophilic and thermostable enzymes that will be highly stable and resistant to product inhibition during these production processes (Arora et al., 2015; Mallerman et al., 2015). Hence, in the present study, we isolated and screened thermophiles (fungi) potentially producing extremophilic lipases, cellulases and proteases, for future biotechnological applications.

\section{MATERIAL AND METHODS}

\section{Collection of samples}

Samples were collected from three different composts site (palm oil mill, wood chip piles and abattoir wastes dumping piles) of Oye-Ekiti, Ekiti State, Nigeria. The samples were obtained from the piles at a depth of 1 meter using a shovel and then transported to the laboratory in sterile polythene bags within 2 hours 
from the collection for microbiological and biochemical study (Alsohaili and Bani-Hasan, 2018).

\section{Screening and isolation of thermophilic fungi}

The thermophiles were isolated by taking $1 \mathrm{~g}$ of different samples of soil and suspending them in $5 \mathrm{~mL}$ of sterile distilled water. These were vigorously vortexed and subsequently placed in the water bath for 24 hours at $70{ }^{\circ} \mathrm{C}$. Then $0.5 \mathrm{~mL}$ of the liquid were inoculated into flasks containing $100 \mathrm{~mL}$ of broth $(4$ $\mathrm{g} / \mathrm{L}$ yeast extract, $20 \mathrm{~g} / \mathrm{L}$ glucose, $1.0 \mathrm{~g} / \mathrm{L} \mathrm{K}_{2} \mathrm{HPO}_{4}, 0.5 \mathrm{~g} / \mathrm{L} \mathrm{MgSO}_{4} \cdot 7 \mathrm{H} 2 \mathrm{O}$, pH $7.0 \pm 0.2)$ and then kept in shaking incubator for other 72 hours at $50^{\circ} \mathrm{C}$. After 72 hours, $200 \mu 1$ samples were taken and inoculated separately on Potato Dextrose Agar (PDA) containing $1 \%$ streptomycin. The plates were incubated at $50^{\circ} \mathrm{C}$ in the dark for 7 days and then colonies observed as described in (Gaddeyya $\boldsymbol{e t}$ al., 2012; Reddy et al., 2014; Alsohaili and Bani-Hasan, 2018).

\section{Screening for thermophilic enzymes}

\section{(i) plate screening for lipases}

The fungi isolated from palm oil mill compost site were screened for lipase production by inoculation on phenol red olive oil agar plates containing $0.01 \%$ (w/v) phenol red, $0.1 \%(w / v) \mathrm{CaCl}_{2}, 1 \%$ (v/v) olive oil, $2 \%(\mathrm{w} / \mathrm{v})$ agar, $1 \%(\mathrm{w} / \mathrm{v})$ streptomycin; the $\mathrm{pH}$ was adjusted to 8.0 using $0.1 \mathrm{~N} \mathrm{NaOH}$. The plates were later incubated at $50^{\circ} \mathrm{C}$ for 5 days (Rai et al., 2014).

(ii) plate screening for cellulases

For this screening the thermophiles obtained from wood chip compost piles, were used. The ability of the isolates to secrete cellulase was tested using Czapek agar plate containing $1 \mathrm{~g} / \mathrm{L}$ carboxymethylcellulose (CMC); $0.5 \mathrm{~g} / \mathrm{L} \mathrm{NaNO}_{3} ; 1 \mathrm{~g} / \mathrm{L}$ $\mathrm{K}_{2} \mathrm{HPO}_{4} ; 0.5 \mathrm{~g} / \mathrm{L} \mathrm{MgSO}{ }_{4} \cdot 7 \mathrm{H}_{2} \mathrm{O} ; 0.001 \mathrm{~g} / \mathrm{L} \mathrm{FeSO} \cdot 7 \mathrm{H}_{2} \mathrm{O} ; 1 \mathrm{~g} / \mathrm{L}$ yeast extract; 15 $\mathrm{g} / \mathrm{L}$ agar) for 5 days at $50^{\circ} \mathrm{C}$. The $\mathrm{pH}$ was regulated to 5.0 . Fungi showing colonies with clear haloes were considered to be positive cellulase producers (Kasana et al., 2008).

(iii) plate screening for proteases

The fungi obtained from abattoir wastes dump site were screened for protease activity on agar medium comprising of $10 \mathrm{~g} / \mathrm{L}$ casein and $20 \mathrm{~g} / \mathrm{L}$ agar at $\mathrm{pH} 8.0$. The inoculated plates were incubated for 5 days at $50^{\circ} \mathrm{C}$ before observing haloes of hydrolysis (de Veras et al., 2018).

\section{Production of thermophilic enzymes}

For enzymes production fungi were inoculated in $250 \mathrm{~mL}$ Erlenmeyer flask containing $100 \mathrm{~mL}$ of the media described below.

\section{(i) lipase production}

The basal medium for lipase production consist of $0.1 \%$ yeast extract, $0.3 \%$ peptone, $0.05 \% \mathrm{CaCl}_{2} .2 \mathrm{H}_{2} \mathrm{O}, 0.05 \% \mathrm{NaCl}, 1 \%$ olive oil and , $0.02 \%$ streptomycin; , pH was adjusted at 8.0 (Ayinla et al., 2017).

(ii) celullase production

Cellulase production in shaking flasks was carried out using Mandels and Weber (1969) medium, supplemented with $1 \% \mathrm{CMC}$ and $2.5 \%$ wheat bran. The medium also consist of $0.2 \% \mathrm{KH}_{2} \mathrm{PO}_{4}, 0.03 \% \mathrm{CaCl}_{2} \cdot 2 \mathrm{H}_{2} \mathrm{O}, 0.03 \%$ urea, $0.03 \%$ $\mathrm{MgSO}_{4} \cdot 7 \mathrm{H}_{2} \mathrm{O}, 0.14 \%\left(\mathrm{NH}_{4}\right)_{2} \mathrm{SO}_{4}, 0.025 \%$ peptone, $0.01 \%$ yeast extract, $1 \mathrm{~mL}$ Tween-80, $0.005 \% \mathrm{FeSO}_{4} \cdot 7 \mathrm{H}_{2} \mathrm{O}, 0.0016 \% \mathrm{MnSO}_{4} \cdot \mathrm{H}_{2} \mathrm{O}, 0.0014 \% \mathrm{ZnSO}_{4} \cdot 7 \mathrm{H}_{2} \mathrm{O}$ and $0.002 \% \mathrm{CoCl}_{2} \cdot 6 \mathrm{H}_{2} \mathrm{O}$, pH 5.0 in $250 \mathrm{~mL}$ Erlenmeyer flask (Saroj et al. 2018).

\section{(iii) protease production}

Submerged fermentation medium for protease production include the following : $1 \%$ of casein, $2.5 \%$ wheat bran, $0.1 \%$ (w/v) of each of $\left(\mathrm{NH}_{4}\right)_{2} \mathrm{SO}_{4}, \mathrm{MgSO}_{4} .7 \mathrm{H}_{2} \mathrm{O}$ and $\mathrm{NH}_{4} \mathrm{NO}_{3}$, to $\mathrm{pH} 8.0$ in $250 \mathrm{~mL}$ Erlenmeyer flasks (Macchione et al., 2008).

Each medium was inoculated with a loopful of actively growing fungal colonies obtained from plates. Inoculated media were placed in a shaking bath and incubated at $50^{\circ} \mathrm{C}$ and with a constant oscillation of $160 \mathrm{rpm}$. After 10 days, the supernatants were obtained by centrifugation at 5,000 rpm for $15 \mathrm{~min}$ at $4^{\mathrm{O}} \mathrm{C}$ and filtered through Whatman no. 1 filter paper before determine their respective enzymatic extracellular activities (Ayinla et al., 2017). The protein contents of all the analyzed supernatants (crude enzyme) were also estimated using Bradford assay (Bradford, 1976).

\section{Measurement of enzyme activity}

(i) assay for lipase

Lipase activity was assayed using Yadav et al. (1993) method with olive oil as substrate. Olive oil $(5 \mathrm{~mL})$ was vigorously mixed with $0.1 \mathrm{M}$ phosphate buffer $(20 \mathrm{~mL})$ and pre-incubated for $10 \mathrm{~min}$ at $37^{\circ} \mathrm{C}$.. The reaction was then activated by the addition of $1 \mathrm{~mL}$ crude enzymes and the mixture incubated for $30 \mathrm{~min}$ at $40^{\circ} \mathrm{C}$. The reaction was finally terminated by the addition of 15 mLacetoneethanol (1:1). Free fatty acids released during the reaction were then titrated with $0.05 \mathrm{~N} \mathrm{NaOH}$ after the addition of three drops of phenolphthalein indicator. One unit of lipase activity was defined as the amount of enzyme which produces $1 \mu \mathrm{mol}$ of fatty acids per minute under assay conditions (Lanka and Trinkle, 2017). (ii) assay for cellulase

Carboxymethyl cellulase (CMCase) was performed according to Ghose (1987) method. The assay was carried out at $50^{\circ} \mathrm{C}$ with a reaction mixture containing 0.5 $\mathrm{mL}$ crude enzyme and $0.5 \mathrm{~mL}$ of $2 \%$ substrate (CMC) dissolved in $50 \mathrm{mM}$ sodium citrate buffer ( $\mathrm{pH} \mathrm{4.8)}$ and incubated for $30 \mathrm{~min}$. After incubation, $3 \mathrm{~mL}$ of DNS (3,5-dinitrosalicylic acid) reagent was added; the mixture was heated for 5 min in boiling water to obtain a coloured reaction mixture and the absorbance measured at $540 \mathrm{~nm}$. One unit of cellulose activity was defined as the amount of enzyme required to liberate $1 \mu \mathrm{mol}$ of glucose from the appropriate substrate per $\mathrm{mL}$ per min under the assay conditions (Saroj et al., 2018).

(iii) assay for protease

Protease activity was determined using Carrie Cupp-Enyard (2008) method This assay utilizes casein as a substrate where $5 \mathrm{~mL}$ of $0.65 \%$ casein solution was incubated for $5 \mathrm{~min}$ at $37^{\circ} \mathrm{C}$. The reaction was then activated by the addition of 1 $\mathrm{mL}$ of crude enzyme solution before heating in water bath for $30 \mathrm{~min}$ at $37^{\circ} \mathrm{C}$. The reaction mixture was terminated by the addition of $5 \mathrm{~mL}$ of Trichloroacetic acid (TCA) solution and filtered using Whatmann No 1 filter paper., $5 \mathrm{~mL}$ of sodium carbonate and $1 \mathrm{~mL}$ of 2 fold diluted Follin Ciocalteus phenol reagent were added to the filtrate before incubating in dark for $30 \mathrm{~min}$ at room temperature for the development of blue colour. The absorbance was measured at $660 \mathrm{~nm}$ against a reagent blank using tyrosine standard. One protease unit was defined as the amount of enzyme that releases $1 \mu \mathrm{M}$ of tyrosine per minute at $\mathrm{pH}$ 7.5 at $37^{\circ} \mathrm{C}$ (Mohapatra et al., 2003; Chandrasekaran et al., 2015).

All the experiments were done in triplicates and values are expressed as mean \pm SEM ( $n=3)$. Statistical analysis was performed using a one-way analysis of variance (ANOVA) followed by Tukey's post hoc test.

\section{Microscopic examination of isolated fungi}

The three fungal isolates from different sources and having the highest enzymatic activities were evaluated for their fungal morphology by observing the colony features (colour, shape, size and hyphae) by a compound microscope Harris HNB-107BN with a digital micro camera MC-D20DU using a lactophenol cotton blue-stained slide mounted with a small portion of the mycelium at $40 \mathrm{X}$ magnification (Gaddeyya et al., 2012; Alsohaili and Bani-Hasan, 2018)

\section{RESULTS AND DISCUSSION}

\section{Screenings of fungal isolate for enzymatic activities}

The thermophilic fungi were isolated from different compost wastes sites namely; palm oil mill, wood chip piles and abattoir wastes dump site at a temperature of 40,40 and $45^{\circ} \mathrm{C}$ respectively at a depth of one meter. All samples were treated at the high temperature of $70^{\circ} \mathrm{C}$ before culturing. All strains were then screened according to the potential enzymatic activity that could occur at the site of sample collection. Thus, the isolate obtained from the palm oil mill, wood chips pills and abattoir dump site were screened for lipase, cellulase and protease activities respectively (Figure 1). The subjection of environmental samples to the high temperature of $70^{\circ} \mathrm{C}$ was used to remove all non-thermophilic microorganisms that were present at the various sites of screening. The rise in temperature has been known to suppress the growth of mesophilic fungi leaving the thermophilic and thermotolerant that are capable of living in environment with high temperatures and thus secreting thermophilic enzymes such as lipases, cellulases and proteases. These enzymes have high potentials in many industrial process (Moretti et al., 2012)
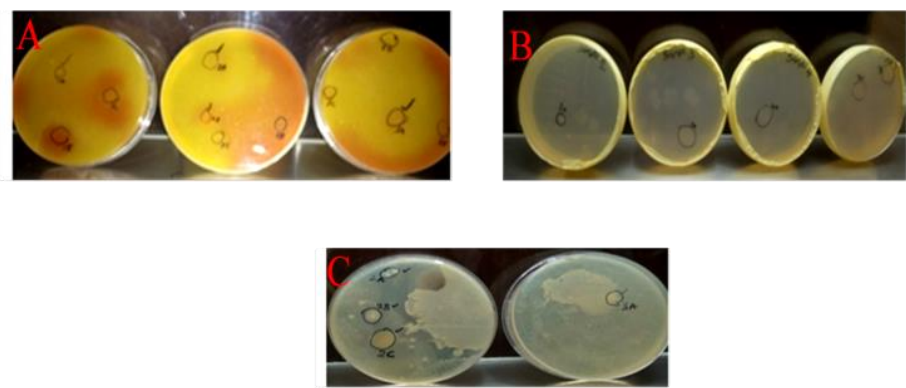

Figure 1 Thermophilic fungi isolates screen for enzymatic activities show zones of hydrolysis. A. Lipase Activity; B. Cellulase Activity; and C. Protease Activity

\section{Quantitative enzyme activity}

The enzymatic analyses were carried out on supernatants after growing newly isolated fungi in Erlenmeyer flask incubated at $50{ }^{\circ} \mathrm{C}$. The culture filtrates were used for quantitative estimation of enzymes activities; results are shown in Tables 1-3. 
Table 1 showed the lipolytic activities of isolates obtained from palm oil mill site; isolate $3 \mathrm{~A}$ had the most proficient lipase activity $(56.562 \mathrm{U} / \mathrm{mL})$ and isolate

$2 \mathrm{~A}$ had the least activity $(41.487 \mathrm{U} / \mathrm{mL})$.

Table 2 showed that four of the five isolates obtained from the wood chip piles had high cellulolytic activity at the end of 10 days incubation period. The cellulase activities of newly isolated thermphilic starins range from $38.352 \mathrm{U} / \mathrm{mL}$ (isolate $3 \mathrm{~A}$ ) to $3.503 \mathrm{U} / \mathrm{mL}$ (isolate $1 \mathrm{~A}$ )

Table 3 showed the proteases activities of isolated thermophiles from abattoir dump site which ranges from $2.054-3.003 \mathrm{U} / \mathrm{mL}$. isolate $2 \mathrm{~B}$ and $3 \mathrm{C}$ had the highest and lowest protease activities respectively.

Table 1 Protein concentration and enzymes activities of lipases in culture filtrate

\begin{tabular}{lcccc}
\hline \multirow{2}{*}{ Table 1 Protein concentration and enzymes activities of lipases in culture filtrate } & $\begin{array}{c}\text { Protein Concentration } \\
(\mathbf{m g} / \mathbf{m L})\end{array}$ & $\begin{array}{c}\text { Fatty Acid Released } \\
(\boldsymbol{\mu g} / \mathbf{m L})\end{array}$ & $\begin{array}{c}\text { Enzyme Activity } \\
(\mathbf{U} / \mathbf{m L} \mathbf{)}\end{array}$ \\
\hline \multirow{3}{*}{ Palm Oil Mill } & Isolates & $0.563 \pm 0.008$ & $1375.474 \pm 0.063$ & $45.253 \pm 0.033$ \\
& 1 A & $1.719 \pm 0.012$ & $1244.343 \pm 0.034$ & $41.482 \pm 0.027$ \\
& 2 A & $0.796 \pm 0.005$ & $1538.464 \pm 0.048$ & $51.281 \pm 0.035$ \\
& 3 A & $0.039 \pm 0.003$ & $1.696 .831 \pm 0.028$ & $56.562 \pm 0.018$ \\
\hline
\end{tabular}

The experiment was performed in triplicates. Values are expressed as mean \pm SEM ( $\mathrm{n}=3$ ). Statistical analysis was performed using a one-way analysis of variance (ANOVA) followed by Tukey's post hoc test. Results were considered statistically significant at $\mathrm{p} \leq 0.05$.

Table 2 Protein concentration and enzymes activities of cellulases in culture filtrate

\begin{tabular}{lcccc}
\hline \multirow{2}{*}{ Samples Site } & Isolates & $\begin{array}{c}\text { Protein Concentration } \\
(\mathbf{m g} / \mathbf{m L})\end{array}$ & $\begin{array}{c}\text { Enzyme Unit } \\
(\boldsymbol{\mu M})\end{array}$ & $\begin{array}{c}\text { Enzyme Activity } \\
(\mathbf{U} / \mathbf{m L})\end{array}$ \\
\hline \multirow{4}{*}{ Wood Chip Piles } & 1 A & $0.489 \pm 0.033$ & $105.011 \pm 0.023$ & $3.503 \pm 0.021$ \\
& 3 A & $0.622 \pm 0.022$ & $1150.522 \pm 0.028$ & $38.352 \pm 0.018$ \\
& 4 A & $0.429 \pm 0.020$ & $375.011 \pm 0.021$ & $12.501 \pm 0.031$ \\
& $7 \mathrm{~A}$ & $0.571 \pm 0.012$ & $392.501 \pm 0.013$ & $13.084 \pm 0.042$ \\
& 7 B & $0.616 \pm 0.028$ & $457.028 \pm 0.016$ & $15.233 \pm 0.023$ \\
\hline
\end{tabular}

The experiment was performed in triplicates. Values are expressed as mean \pm SEM ( $\mathrm{n}=3$ ). Statistical analysis was performed using a one-way analysis of variance (ANOVA) followed by Tukey's post hoc test. Results were considered statistically significant at $\mathrm{p} \leq 0.05$.

Table 3 Protein concentration and enzymes activities of proteases in culture filtrate

\begin{tabular}{lllll} 
Samples Site & Isolates & $\begin{array}{l}\text { Protein Concentration } \\
(\mathbf{m g} / \mathbf{m L})\end{array}$ & $\begin{array}{l}\text { Enzyme Unit } \\
(\boldsymbol{\mu M})\end{array}$ & $\begin{array}{l}\text { Enzyme Activity } \\
(\mathbf{U} / \mathbf{m L})\end{array}$ \\
\hline \multirow{3}{*}{ Abattoir Dump Site } & 2 A & $0.852 \pm 0.013$ & $6.163 \pm 0.028$ & $2.054 \pm 0.018$ \\
& 2 B & $0.369 \pm 0.008$ & $9.014 \pm 0.021$ & $3.003 \pm 0.009$ \\
& 2 C & $0.537 \pm 0.011$ & $6.474 \pm 0.013$ & $2.162 \pm 0.012$ \\
& 3 C & $0.298 \pm 0.009$ & $6.233 \pm 0.018$ & $2.081 \pm 0.013$ \\
\hline
\end{tabular}

The experiment was performed in triplicates. Values are expressed as mean \pm SEM $(n=3)$. Statistical analysis was performed using a one-way analysis of variance (ANOVA) followed by Tukey's post hoc test. Results were considered statistically significant at $\mathrm{p} \leq 0.05$.

\section{Microscopic and morphological identification of fungi isolates}

Microscopic and morphological identification were carried on fungi isolates with the highest enzymatic activities (Figure 2). Lipases producing isolate $3 \mathrm{~A}$ obtained from the palm oil mill (Figure 2A) indicated the presence of dark colonies with root-like rhizoids and branching hyphae and identified as Rhizopus sp. The cellulases producing isolate $3 \mathrm{~A}$ obtained from wood chip piles (Figure 2B) indicated massive mycelium with narrow branched hyphae and yellowish green spores and identified as Aspergillus flavus. The proteases producing isolate 2B obtained from abattoir wastes dumping site (Figure 2C) showed widely spread colonies with yellowish brown and darkened annular structures and identified as Neurospora sp.

The 3 fungal strains presently isolated in this work corroborate the result obtained by Maheshwari et al. (2000) who reported that few species of thermophiles have been identified and described out of 75,000 known fungi. After qualitative tests performed on plates, the quantitative enzymatic tests that were also conducted using the supernatants obtained from the liquid cultures in aerated Erlenmeyer flasks, corroborate that these strains are efficient producers of thermophilic enzymes.

Previous studies showed that that aerated shake flask cultures compared to static cultures are essential for the production of enzymes with high activity (Papagora et al., 2013). Salleh et al. (1993), Essamri et al. (1998) and Mukhtar et al. (2016) reported that Rhizopus oryzae are excellent producer of high activity lipase. This corroborate our microscopic analysis showing that of the isolate with the highest lipase activity was Rhizopus sp. Aspergillus flavus was identified as the isolate with the highest cellulolytic activity, confirming results obtained by Chandra et al. (2007) who found that secreted cellulolytic enzymes from Aspergillus flavus are responsible for the degradation of cellulosic material. Furthermore, the extracellular production of proteases by isolates obtained from abattoir wastes dump site showed growth and enzyme production at $\mathrm{pH} 8.0$ and $50{ }^{\circ} \mathrm{C}$. This result is similar with what was obtained from Thermomyces lanuginose P134 (Li et al., 1997) and Tritirachium albumlimber (Samal et al. 1991) that also grew optimally at $50{ }^{\circ} \mathrm{C}$ as Neurospora sp. obtained from this study.

Microscopic analysis allowed the identification of the thermophilic isolates with the highest enzymatic activities. Screening for thermophiles at a depth of 1 meter below ground surface facilitated obtaining viable isolates, however the temperature and moisture content obtained at this depth was assumed be adequate enough for their survival and optimum growth (Rajasekaran and Maheshwari, 1993; Pedersen, 2000)

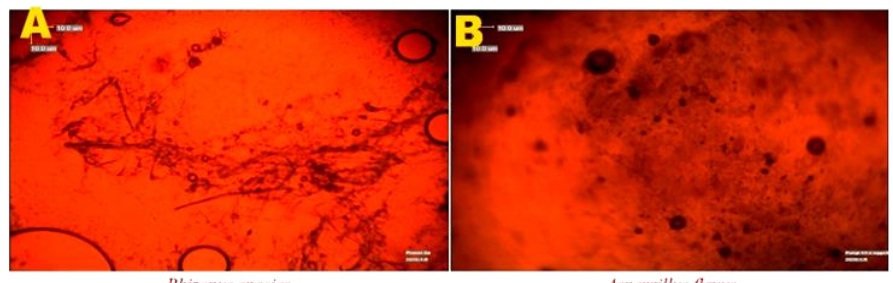

Rhizopus species

Aspergillw flow

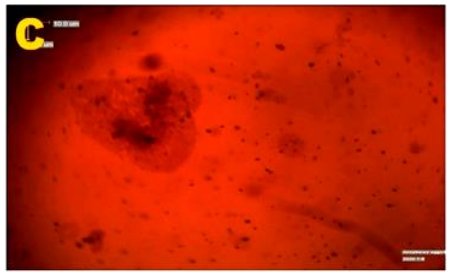

Neurospora species

Figure 2 Microscopic and morphological analyzes of thermophilic fungi with the highest enzymatic activities. [A] Rhizopus sp. from isolate $3 \mathrm{~A}$ obtained from palm oil mill; [B] Aspergillus flavus from isolate 3A obtained from wood chip piles; [C] Neurospora sp. from isolate $2 \mathrm{~B}$ obtained from abattoir dumping site.

\section{CONCLUSION}

Enzymes are liable to denaturation at high temperature thereby causing inhibition of growth and other metabolic activities in microorganism (Pundir et al., 2012). Thus, the need for desired good level of activity and enhanced stability at higher temperature are factors to be considered for enzyme selection (Moretti et al. 2012). This study therefore allowed the isolation and identification of thermophilic fungi (Rhizopus sp., Aspergillus flavus and Neurospora sp.) that can withstand high temperature alongside producing thermostable enzymes with highly significant activities. The obtained result indicate that all the isolates are potent producer of extracellular thermophilic hydrolytic enzymes (lipase, 
cellulase and protease) working at a temperature of $50{ }^{\circ} \mathrm{C}$. This evidence suggests that these thermophilic fungi could be of great advantage in various industrial processes. Thus, more further studies are needed for the biochemical and molecular characterization of these isolates to strengthen our understanding of their metabolic activities. Detailed knowledge of the catalytic and biophysical properties of these thermophilic enzymes are very critical towards bioengineering of these isolates to withstand extreme industrial processes or environmental conditions.

Acknowledgements: The authors sincerely want to appreciate Professor S.V.A Uzochukwu, the Director of Biotechnology Centre, Federal University Oye Ekiti, Nigeria for providing the laboratory space used for this work, and also Federal University Oye Ekiti, Nigeria for academic supports.

\section{REFERENCES}

Ahirwar, S., Soni, H., Prajapati, B. P., and Kango, N. (2017). Isolation and screening of thermophilic and thermotolerant fungi for production of hemicellulases from heated environments. Mycology, 8(3), 125134.https://doi.org/10.1080/21501203.2017.1337657

Alsohaili, S. A., and Bani-Hasan, B. M. (2018). Morphological and Molecular Identification of Fungi Isolated from Different Environmental Sources in the Northern Eastern Desert of Jordan. Jordan Journal of Biological Sciences, 11(3). Aravindan, R., Anbumathi, P., and Viruthagiri, T. (2007). Lipase applications in food industry. Indian Journal of Biotechnology, 6(2).

Arora, R., Behera, S., and Kumar, S. (2015). Bioprospecting thermophilic/thermotolerant microbes for production of lignocellulosic ethanol: a future perspective. Renewable and Sustainable Energy Reviews, 51, 699717.https://doi.org/10.1016/j.rser.2015.06.050

Aruna, K., Shah, J., and Birmole, R. (2014). Production and partial characterization of alkaline protease from Bacillus tequilensis strains CSGAB0139 isolated from spoilt cottage cheese. Int J Appl Biol Pharm, 5, 201221.

Ayinla, Z. A., Ademakinwa, A. N., and Agboola, F. K. (2017). Studies on the optimization of lipase production by Rhizopus sp. zac3 isolated from the contaminated soil of a palm oil processing shed. Journal of Applied Biology and Biotechnology Vol, 5(02), 030-037.

Bradford, M. M. (1976). A rapid and sensitive method for the quantitation of microgram quantities of protein utilizing the principle of protein-dye binding Analytical biochemistry, 72(1-2), 248-254.https://doi.org/10.1016/00032697(76)90527-3

Chandra, M. S., Viswanath, B., and Reddy, B. R. (2007). Cellulolytic enzymes on lignocellulosic substrates in solid state fermentation by Aspergillus niger Indian Journal of Microbiology, 47(4), 323-328.https://doi.org/10.1007/s12088007-0059-x

Chandrasekaran, S., Kumaresan, S. S. P., and Manavalan, M. (2015). Production and optimization of protease by filamentous fungus isolated from paddy soil in Thiruvarur District Tamilnadu. Journal of Applied Biology and Biotechnology, 3(06), 066-069.

Chrisnasari, R., Verina, D., Tapatfeto, A. C., Pranata, S., Patjajani, T., Wahjudi, M., and Purwanto, M. G. M. (2018). Isolating and Characterising Chitinolytic Thermophilic Bacteria from Cangar Hot Spring, East Java. Pertanika Journal of Tropical Agricultural Science, 41(3).

Cupp-Enyard, C. (2008). Sigma's non-specific protease activity assay-casein as a substrate. JoVE (Journal of Visualized Experiments)(19), e899.https://doi.org/10.3791/899

de Veras, B. O., dos Santos, Y. Q., Diniz, K. M., Carelli, G. S. C., and dos Santos, E. A. (2018). Screening of protease, cellulase, amylase and xylanase from the salt-tolerant and thermostable marine Bacillus subtilis strain SR60. F1000Research, 7(1704), 1704.https://doi.org/10.12688/f1000research.16542.1

Dervilly, G., Leclercq, C., Zimmermann, D., Roue, C., Thibault, J.-F., and Saulnier, L. (2002). Isolation and characterization of high molar mass watersoluble arabinoxylans from barley and barley malt. Carbohydrate polymers, 47(2), 143-149.https://doi.org/10.1016/S0144-8617(01)00172-2

Essamri, M., Deyris, V., and Comeau, L. (1998). Optimization of lipase production by Rhizopus oryzae and study on the stability of lipase activity in organic solvents. Journal of Biotechnology, 60(1-2), 97 103.https://doi.org/10.1016/S0168-1656(97)00193-4

Gaddeyya, G., Niharika, P. S., Bharathi, P., and Kumar, P. (2012). Isolation and identification of soil mycoflora in different crop fields at Salur Mandal. Advances in Applied Science Research, 3(4), 2020-2026.

Ghose, T. (1987). Measurement of cellulase activities. Pure and applied Chemistry, 59(2), 257-268.https://doi.org/10.1351/pac198759020257

Gomes, J., and Steiner, W. (2004). The biocatalytic potential of extremophiles and extremozymes. Food technology and Biotechnology, 42(4), 223-225.

Gulmus, E. O., and Gormez, A. (2020). Identification and characterization of novel thermophilic bacteria from hot Springs, Erzurum, Turkey. Current Microbiology, 1-9.
Kabir, F., Sultana, M. S., and Kurnianta, H. (2015). Polyphenolic contents and antioxidant activities of underutilized grape (Vitis vinifera L.) pomace extracts. Preventive nutrition and food science, 20(3), 210.https://doi.org/10.3746/pnf.2015.20.3.210

Kasana, R. C., Salwan, R., Dhar, H., Dutt, S., and Gulati, A. (2008). A rapid and easy method for the detection of microbial cellulases on agar plates using Gram's iodine. Current Microbiology, 57(5), 503-507.

Lanka, S., and Trinkle, T. (2017). Screening and isolation of lipase producing fungi from marine water obtained from Machilipatnam costal region. International Journal of Pharmacognosy and Phytochemical Research, 9(7), 928-932.https://doi.org/10.25258/phyto.v9i07.11157

Lee, H., Lee, Y. M., Jang, Y., Lee, S., Lee, H., Ahn, B. J., Kim, G.-H., and Kim, J.-J. (2014). Isolation and analysis of the enzymatic properties of thermophilic fungi from compost. Mycobiology, 42(2), 181 184.https://doi.org/10.5941/MYCO.2014.42.2.181

Li, D.-C., Yang, Y.-J., and Shen, C.-Y. (1997). Protease production by the thermophilic fungus Thermomyces lanuginosus. Mycological Research, 101(1), 18-22.https://doi.org/10.1017/S0953756296002109

Macchione, M. M., Merheb, C. W., Gomes, E., and Da Silva, R. (2008). Protease production by different thermophilic fungi. Applied Biochemistry and Biotechnology, 146(1-3), 223-230.https://doi.org/10.1007/s12010-007-8034-x

Maheshwari, R., Bharadwaj, G., and Bhat, M. K. (2000). Thermophilic fungi: their physiology and enzymes. Microbiol. Mol. Biol. Rev., 64(3), 461488.https://doi.org/10.1128/MMBR.64.3.461-488.2000

Mallerman, J., Papinutti, L., and Levin, L. (2015). Characterization of $\beta$ glucosidase produced by the white rot fungus Flammulina velutipes. $J$ Microbiol Biotechnol, 25(1), 57-65.https://doi.org/10.4014/jmb.1401.01045

Mandels, M., and Weber, J. (1969). The production of cellulases. In. ACS Publications.https://doi.org/10.1021/ba-1969-0095.ch023

Mohapatra, B., Bapuji, M., and Sree, A. (2003). Production of industrial enzymes (amylase, carboxymethylcellulase and protease) by bacteria isolated from marine sedentary organisms. Acta Biotechnologica, 23(1), 75 84.https://doi.org/10.1002/abio.200390011

Moretti, M., Bocchini-Martins, D. A., Silva, R. D., Rodrigues, A., Sette, L. D., and Gomes, E. (2012). Selection of thermophilic and thermotolerant fungi for the production of cellulases and xylanases under solid-state fermentation. Brazilian Journal of Microbiology, 43(3), 1062-1071.https://doi.org/10.1590/S151783822012000300032

Mukhtar, H., Khursheed, S., Mumtaz, M. W., Rashid, U., and Al-Resayes, S. I (2016). Optimization of lipase biosynthesis from Rhizopus oryzae for biodiesel production using multiple oils. Chemical Engineering and Technology, 39(9), 1707-1715.https://doi.org/10.1002/ceat.201500584

Papagora, C., Roukas, T., and Kotzekidou, P. (2013). Optimization of extracellular lipase production by Debaryomyces hansenii isolates from drysalted olives using response surface methodology. Food and Bioproducts Processing, 91(4), 413-420.https://doi.org/10.1016/j.fbp.2013.02.008

Patel, N. S., Fung, S. M., Zanichelli, A., Cicardi, M., and Cohn, J. R. (2013).

Ecallantide for treatment of acute attacks of acquired $\mathrm{C} 1$ esterase inhibitor deficiency. Allergy and Asthma Proceedings.https://doi.org/10.2500/aap.2013.34.3620

Pedersen, K. (2000). Exploration of deep intraterrestrial microbial life: current perspectives. FEMS microbiology letters, 185(1), 16.https://doi.org/10.1111/j.1574-6968.2000.tb09033.x

Pundir, R. K., Rana, S., and Tyagi, H. (2012). Studies on compatibility of fungal alkaline protease with commercially available detergents. Int. J. Mod. Biochem, 1(1), 41-56.

Rai, B., Shrestha, A., Sharma, S., and Joshi, J. (2014). Screening, optimization and process scale up for pilot scale production of lipase by Aspergillus niger. Biomed. Biotechnol, 2, 54-59.

Rajasekaran, A., and Maheshwari, R. (1993). Thermophilic fungi: an assessment of their potential for growth in soil. Journal of biosciences, 18(3), 345354.https://doi.org/10.1007/BF02702992

Raut, M., William, S. P., Bhattacharyya, J., Chakrabarti, T., and Devotta, S. (2008). Microbial dynamics and enzyme activities during rapid composting of municipal solid waste-a compost maturity analysis perspective. Bioresource Technology, 99(14), 6512-6519.https://doi.org/10.1016/j.biortech.2007.11.030 Raveendran, S., Parameswaran, B., Beevi Ummalyma, S., Abraham, A., Kuruvilla Mathew, A., Madhavan, A., Rebello, S., and Pandey, A. (2018). Applications of microbial enzymes in food industry. Food technology and Biotechnology, 56(1), 16-30.https://doi.org/10.17113/ftb.56.01.18.5491

Reddy, P. L. N., Babu, B. S., Radhaiah, A., and Sreeramulu, A. (2014). Screening, identification and isolation of cellulolytic fungi from soils of Chittoor district, India. International Journal of Current Microbiology and Applied Sciences, 3(7), 761-771.

Salleh, A. B., Musani, R., Basri, M., Ampon, K., Yunus, W., and Razak, C. (1993). Extra-and intra-cellular lipases from a thermophilic Rhizopus oryzae and factors affecting their production. Canadian journal of microbiology, 39(10), 978-981.https://doi.org/10.1139/m93-147

Samal, B. B., Karan, B., Parker, C., and Stabinsky, Y. (1991). Isolation and thermal stability studies of two novel serine proteinases from the fungus 
Tritirachium album Limber. Enzyme and microbial technology, 13(1), 6670.https://doi.org/10.1016/0141-0229(91)90190-L

Saroj, P., Manasa, P., and Narasimhulu, K. (2018). Characterization of thermophilic fungi producing extracellular lignocellulolytic enzymes for lignocellulosic hydrolysis under solid-state fermentation. Bioresources and Bioprocessing, 5(1), 31.https://doi.org/10.1186/s40643-018-0216-6

Schülein, M. (1988). Cellulases of Trichoderma reesei. In Methods in enzymology (Vol. 160, pp. 234-242). Elsevier.https://doi.org/10.1016/0076-6879(88)60125-X Yadav, R., Saxena, R., Guptha, R., and Davison, S. (1993). Lipase by Aspergillus and Penicillium species. Int J Food Microbiol, 19, 217-227.

Yandri, T. S., Dian, H., and Sutopo, H. (2008). The chemical modification of protease enzyme isolated from local bacteria isolate, Bacillus subtilis

ITBCCB148 with cyanuric chloride polyethylenglycol. European Journal of Scientific Research, 23(1), 177-186. 